\title{
WANDERING WOMEN IN FRENCH FILM AND LITERATURE
}


This page intentionally left blank 


\title{
WANDERING WOMEN IN FRENCH FiLM AND Literature
}

\author{
A STUdy OF \\ NarRative Drift
}

Mariah Devereux Herbeck

\section{palgrave macmillan}




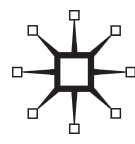

WANDERING WOMEN IN FRENCH FILM AND LITERATURE

Copyright (C) Mariah Devereux Herbeck, 2013.

Softcover reprint of the hardcover 1st edition 2013 978-1-137-33998-0

All rights reserved.

First published in 2013 by

PALGRAVE MACMILLAN ${ }^{\otimes}$

in the United States-a division of St. Martin's Press LLC,

175 Fifth Avenue, New York, NY 10010.

Where this book is distributed in the UK, Europe and the rest of the world, this is by Palgrave Macmillan, a division of Macmillan Publishers Limited, registered in England, company number 785998, of Houndmills, Basingstoke, Hampshire RG21 6XS.

Palgrave Macmillan is the global academic imprint of the above companies and has companies and representatives throughout the world.

Palgrave ${ }^{\circledR}$ and Macmillan ${ }^{\circledR}$ are registered trademarks in the United States, the United Kingdom, Europe and other countries.

ISBN 978-1-349-46464-7

ISBN 978-1-137-33999-7 (eBook)

DOI $10.1057 / 9781137339997$

Library of Congress Cataloging-in-Publication Data is available from the Library of Congress.

A catalogue record of the book is available from the British Library.

Design by Newgen Knowledge Works (P) Ltd., Chennai, India.

First edition: October 2013

109876654321 
For my mom, Nancy. 
This page intentionally left blank 


\section{CONTENTS}

Acknowledgments

Introduction 1

1 An Introduction to Narrative Drift 9

2 “Qui suis-je?" 35

3 "Impersonal" Narrative: Fade to Lack-Detachment and Discontinuity 61

4 "Personal" Narrative: Taking It Personally-Men Telling the Stories of Wandering Women 87

5 "Pluralized" Narrative: More Is Less? The Paradox of Pluralized Perspectives

$\begin{array}{ll}\text { Conclusion } & 157\end{array}$

$\begin{array}{ll}\text { Notes } & 167\end{array}$

Bibliography 183

Index 191 
This page intentionally left blank 


\section{ACKNOWLEDGMENTS}

Wandering Women in French Film and Literature: A Study of Narrative Drift is based largely on work completed for my doctoral dissertation at the University of Wisconsin-Madison. I am eternally grateful to my dissertation advisor, Steven Winspur-who read many drafts of this work in its infancy and provided invaluable advice and guidance. I also wish to thank my committee-Kelley Conway, Susan Bernstein, and Patrick Rumble-for all their suggestions and support for this interdisciplinary project.

Portions of chapters 2 and 4 of this book have appeared in earlier form in articles published by Dalhousie French Studies ("André Breton's Nadja: A Vagabonde in a Femme Fatale's Narrative" [Spring 2008, 163-171]) and French Literature Series ("Narrative Assault Laetitia Masson's A vendre" [Vol. XXXV, 153-163]). I thank the editors of these journals for graciously granting me permission to integrate elements of both of these articles into this book.

I wish to thank my colleagues in the department of World Languages at Boise State University who have been incredibly supportive of my work. As well, I would like to thank Boise State's College of Arts and Sciences for a "Block Grant" in the form of a course release that allowed me to devote much needed time to revisions of my manuscript.

My editors at Palgrave, Robyn Curtis and Brigitte Shull, have been exceedingly supportive, helpful and all around wonderful to work with. As well, when I reflect on the spot-on suggestions provided by the anonymous reviewers at Palgrave who chose to read my manuscript, I cannot help but be reminded of the expression "the kindness of strangers." I am so appreciative 
of the time they took to read and reflect on my work-their suggestions have been invaluable to this project.

I must thank the exceptional teachers without whom, frankly, this book would have been impossible. To name only a few, Donna Grundstad sparked my initial interest in the French language in sixth grade at Robert Lucas Elementary in Iowa City, Iowa, with her creative activities and croissants. At Mount Holyoke College, Chris Rivers introduced me to the exciting world of subversive female characters in his femme fatale course and encouraged me unfalteringly to pursue graduate studies in French. At the University of Wisconsin-Madison, Peter Schofer's courses on French cinema inspired me to learn as much as I could about the field of Film Studies; the numerous film books that he gave me, a poor graduate student, also helped my endeavor immensely.

My first teacher, my mom, Nancy Van Allen, helped hone my ability for critical thought from a very young age by teaching me to question presentations of gender identity, wherever and whenever possible ("why do these advertisers think that only moms buy peanut butter?"). A big thanks to her and her partner, Don Griffin, for their expert babysitting skills that allowed me to carve out much needed time to work on this book.

Thank you to my Mount Holyoke College friends, Amy Pacifico, Abby Greiner, Sharon King, Shannon LaDeau, and Kristin C. Young, who taught me not to sweat the small stuff (often while singing and wearing ridiculous glasses). Their life lessons and advice have been invaluable to my work.

Finally, this project would still be collecting dust on the shelf if it were not for Jason Herbeck's unwavering faith in me and my work. He has been, and always will be, my first and best reader. Thank you also to beautiful Sidonie, whose love of books spurs us, her parents, to write as well as we can, knowing someday (sooner than we know it) she will read what we have written.

And, last but not least, I must thank our Golden Retriever mix, Maize. Without her gentle reminders (i.e., nudging my elbow so hard that my hand would fly off the keyboard), I would have forgotten to go on all those walks in the fresh air that undoubtedly helped the writing process. 